\title{
Therapeutic muds
}

\section{Munteanu Constantin ${ }^{1}$, Mioara Dumitrascu ${ }^{2}$ ${ }^{1}$ Institutul Național de Recuperare, Medicina Fizica şi Balneoclimatologie ${ }^{2}$ S.C. BIOSAFETY SRL-D}

As defined by the "International Society of Medical Hydrology" muds (peloids) are "substances formed under natural conditions under the influence of geological processes and in a state finely divided and mixed with water, that are used in medical practice in general or local baths.

The complex geological structure and geographical location of Earth's crust, Romania has a great wealth of natural factors: mineral waters, muds, moffets, salt lakes - spread over almost the entire surface of the country.

Use of mud in therapy began in the second half of the XIX century to Techirghiol (mud) and Vatra Dornei (peat mud from Poiana Stampei and Copaceni), while extending the therapy practiced in various spas on the Black Sea. Initially were used by primitive means, that today offer spa resorts and to be highly diverse for both social and mass tourism, as well as the luxury.

Mud is a soil with pasty consistency rocks used as therapeutic remedies of since ancient times. Some beneficial effects of mud are empirically known from ancient times, others have recently been studied and described, some have remained and today the stage brief explanations. Mud treatment is also called peloidotherapy, it should be used only for the indication and under medical supervision.

The most common therapeutic mud bank are deposits of salt ponds - sulphurous black mud, which forms the bottom of marine estuaries, bays and lakes of continental salt.
After the formation, organic and inorganic materials present in sediments, muds are divided into three groups:

\section{1. sapropelic mud \\ 2. peat mud \\ 3. mineral mud}

The degree of mineralization of mud solution varies from $0.01 \mathrm{~g} / 1$ in sapropelic mud and peat, up to $350 \mathrm{~g} / 1$ in the sulfide.

Between mud and water solution that permanently covers diffusion processes have I.O.C, whose job is to maintain a balance between them, in terms of salt ions.

Gases arefound in muds especially in soluble state; the mainly source of their formation are the biochemical processes in solution from which hydrogen sulphide accumulates mud, carbon dioxide, nitrogen, oxygen and methane.

1. Sapropelic mud deposits are represented by black colloidal iron rich hydrosulfuric, they look plastic and greasy, salty water can be found at the bottom of microorganisms with the origin of the flora and fauna of water bodies that are also associated minerals or inorganic the lake basin from the ground.

Flora consists of algae and macrophyte type revails microfiche Cladophora vagabunda, Cladophora cristalina, algae that grow in salt water only.

Aquatic fauna Artemia salina species is represented of $10-12 \mathrm{~mm}$ red organisms.

The bodies of Artemia salina, bacterial decomposition, together with algae Cladophora cristalina form mud. 


\section{Examples:}

* sapropelic muds coasts and lakes (Techirg hiol Agigea, etc.)

* sapropelic muds of continental lakes (Am ara, background, etc.)

* sludge fossils (Ocna Sibiu, Sovata, etc.)

2. Peat mud is formed by decomposition of plant debris on the bottom of lakes/wetlands under the action of microorganisms. They are brown and rich in organic matter and humic acids, waxes, pectin, cellulose, etc. In our country can be found in:

\section{* Vatra Dornei \\ * Borsec.}

3. Mineral mud-are formed by sedimentation of carbonated springs, calcium, ferruginous or sulfur.
\$ sulfur springs sulfur
$\boldsymbol{X}$ springs baths Sângeorz-Săcelu
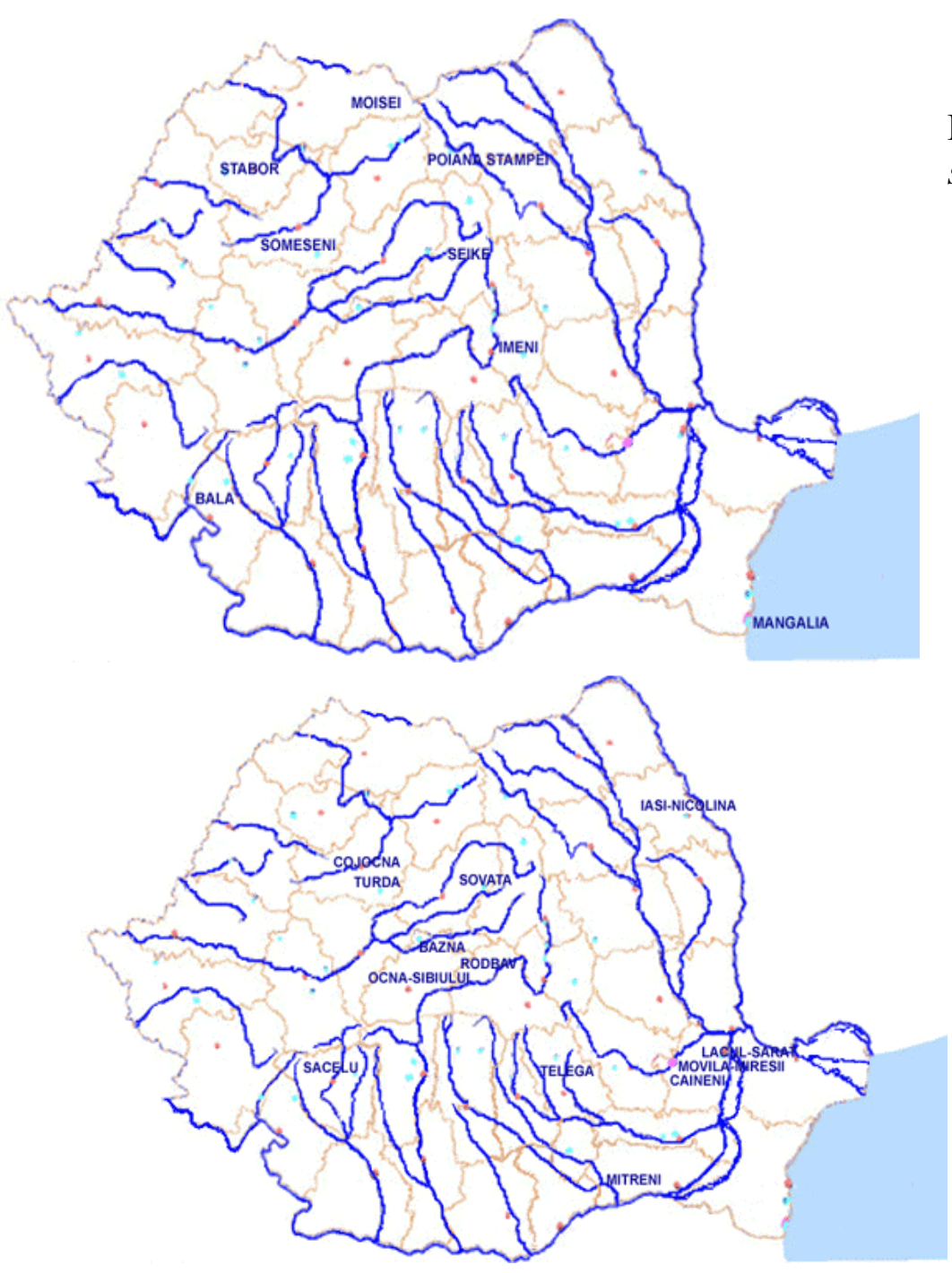

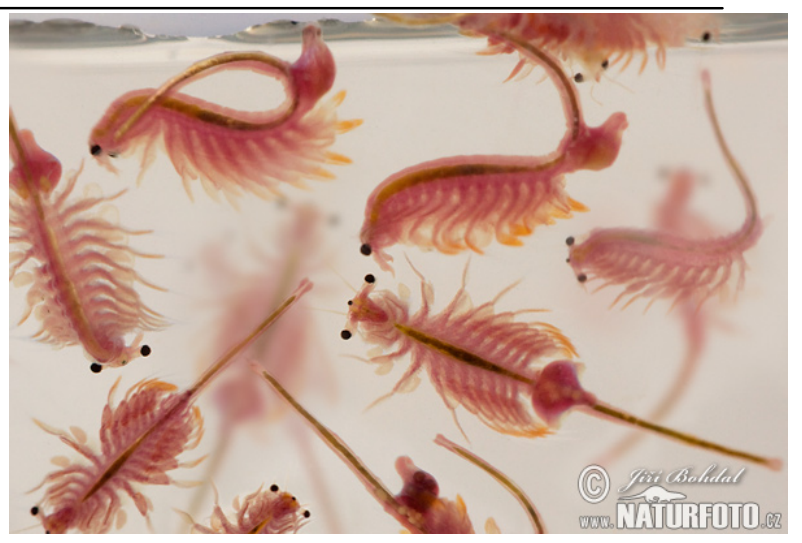

http://www.hawaii.edu

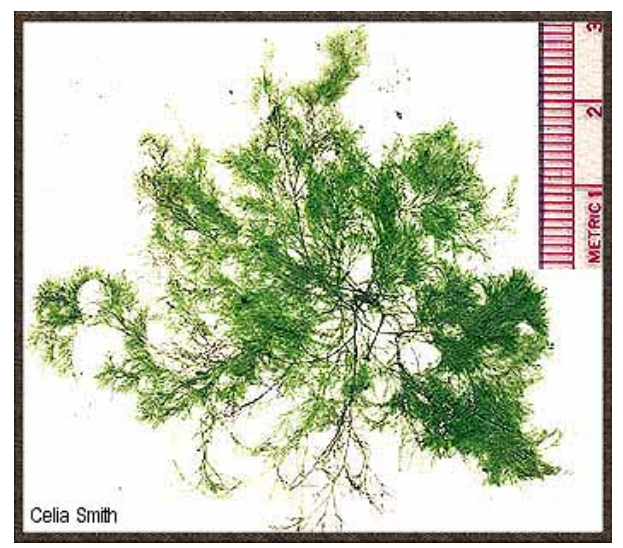

http://www.naturephoto-cz.eu

Figura 1. Cladophora vagabunda and Artemia salina.

Figura 2. Principalele staţiuni din România cu nămoluri de turbă

Figura 3. Principalele stațiuni din România cu nămoluri minerale 
The physico-chemical, the mud is a heterogeneous system physico-chemically composed of a liquid phase containing water soluble mineral bath salts in the water, a solid phase containing substances such as minerals and organic and a gas phase which contains hydrogen sulphide. The ionic balance of a mud is reflected on the $\mathrm{pH}$. Generally, namolurile are alkaline $\mathrm{pH}$ $=9-10$. Therapeutic effect of the mud is given by the combination of physical and chemical properties.

- solid phase is mostly the domain ultramicroeterogen, colloidal-mixed composition and molecular contaminants

- liquid phase is represented by the water soluble solution humor and inorganic and organic form of the structural aspect of the solution of solid particles imbibatie interstitiala.

- the gas phase is the result of processes biochemical and physicochemical conducted during the natural peloidogenezei and consists mainly of his of hydrocarbons, CO2, H2S2, O2, H2.

\section{The main quality indicators are:}

- macroscopic properties-in particular those with references to the color and consistency of physics;

- degree of hydration in the sediment of peloid heterogen according to share of the global composition of moisture:

-low-hydrated peloide $<37 \%$

-hydrated peloide $37-40 \%$

-strongly hydrated peloide $40-70 \%$

- peloidogenetic Stage of evolution as the corresponding degree of therapeutic peloid decomposition of organic substances, depending on the ratio between the quantity of organic substances such as main classes (carbs, protein, humice, organic carbon/organic nitrogen) and biological consumption level oxygen, $\mathrm{CBO}_{5}$ :

- peloids (sapropelic organic, or genetically e volved tendencies mineralization

- peat with varying degrees of decomposition of organic matter;

- weakly decomposed peat

- early decomposed peat;
- well decomposed peat.

\section{Physical properties of muds}

- hydropexic capacity - absorption capacity and water retention, practice value-peloids with low hydropexic capacity (mineral sludge) are used only for packaging, those with average hydropexic capacity (sapropelic mud) and large (peat sludge) can be used for bathrooms.

- plasticity-the property to change shape under the action of external forces, is given by the solids content, low plasticity (mineral mud), medium (peat) and high (sapropelic).

- dispersion-date peloid grain size; therapeutic value is directly proportional to grain size.

- density or specific gravity, is given by its components. Therapeutic value is inversely proportional to the density of the mud.

- thermopexic capacity -absorb and retain heat. Peloids have a high capacity to retain heat.

\section{Chemical properties}

- peloid-water is the most important component, proportional to the amount of colloids

- minerals depends on the structure-rock and water in the basin. The largest amount of mineral substances have mineral sludge (50-70\%), then the sapropelic (20-40\%) and peat (below 20\%).

\section{Pharmaco-dynamic properties}

As a biological material used in human therapy analysis is carried out according to the methods specified in "Romanian Pharmacopoeia" with some additions made inthe working methods used for soil analysis. The result takes the form of physical- chemical analysis report.

In applying of peloids to the skin occurring a series of processes:

- receiving sensory of the qualities / properties of sludge and their transfer to higher levels of integration and control;

- exchange of energy and substance with environment of peloid ;

- fulfillment of adaptive controls: circulatory (peripheral circulation thermoregulation), 
secretory (sweating), protection (keratinization, melanogenesis, lipid film formation);

- integration skin effects of mud application in general physiology of the body: thermoregulation, vitamin D synthesis, optimization of homeostatic balance: immune, endocrine and neurovegetative body.

Mud application on the entire surface of the skin tissue triggers local reactions and general functioning, inhibiting or activating certain enzymes and metabolites intermediate systems. Balneary cure with mud has positive effects persisting for a long time by modifying the adaptive capacity to respond to various stimuli.

\section{Peloids act on:}

- the cardiovascular system - stimulate cardiovascular reactions with emphasis on central hemodynamics and peripheral mechanisms. Deposit mobilization occurs immediately blood and their involvement in general circulation, inflammatory processes.

- nervous system - sedative or stimulating effects on the central nervous system and SNV by sedation of pain receptors. Balneary cure with mud increases the antimicrobial defense capacity by increasing phagocytic power of leucocytes, as evidenced bychanges opsonocitofagic index (I.O.C)

- immunological systemscontrol immunoglobulin values, increased non-specific immunity, etc. Enzymatic and metabolic changes occurring in the endocrine glands after peloidotherapy varies by specific secretory gland, after which functional status is related to the type gland andtherapeutic applications.

Under the action of mud occurs in all glands harmonic stimulation to increase enzyme activity and synthesis while maintaining the specificity of each. Harmonization activities related to endocrine function is stimulation of hypothalamic- pituitary-adrenal translated by optimizing plasma levels: $\beta$-endorphin.

Endocrine mechanism is involved in induction of anti-inflammatory effects by modulating the activity pelotherapy hypothalamic-pituitary-adrenal and endocrine balance of general equilibrium effects and postcure persistent. Responsiveness tochemical mediators - acetilcholina and adrenaline ý and the face of ions correlated with autonomic activity, $\mathrm{Ca}, \mathrm{Mg}, \mathrm{K}$ - is increased by external treatment with mud, andautonomic tone has a tendency to control / normalization, which leads to vegetativestigmata remedy.

\section{Application methods of peloids:}

Unction with mud - is the oldest method involves the application of cold mud on the patient's skin (after itwas heated for 10-15 minutes) in a thin layer on limited areas or the entire body. The patient must then expose to the sun, in an upright position until the mud dries, about30-60 minutes, followed by 10 to 15 in sea water bath or moving to the lakeaccompanied by a brief shower in cold water and rest in bed at least an hour. It is a method of application mechanisms thermoregulation, neuroendocrine stimulation andadaptation processes by alternating hot-cold contrast factors.

Mud packs - consist of mud application in 1-2 cm layer heated to 38-46 ý C limited region or all over your body for 20-40 minutes.

Cataplasms- mud applications at different temperatures on limited regions of the body.

Mud baths - in baths with heated lake water plus 10-12 kg mud, increasing its concentration progressively to $10-25 \%$. The mixture can be heated to 44 ýC. In patients with cardiovascular disease, the temperature should not exceed 37 ý $\mathrm{C}$, and for those withinflammatory rheumatic disease in 36ý C. The bath is 20-40 minutes. Shower bath should be followed by the 37-38 ýC and minimum rest hour. A treatement consists of 12-15 daily baths.

Gynecological applications- vaginal swabs as with mud at 39-40 ýC for 2 hours or vaginal irrigation with mud dissolved in lake water and heated to $37^{\circ} \mathrm{C}$.

Massage with mud - with mud stretching and massaging. 
Tabel 1. Peloiodoterapia is used for the following diseases:

\begin{tabular}{|ll|}
\hline \multirow{2}{*}{ Locomotor System } & - degenerative rheumatism with different locations: column \\
& (spondylosis, discopatii simple chronic low back, etc.), \\
& peripheral (coxarthrosis, gonartroze, etc.) \\
& - inflammatory rheumatism \\
& - rheumatism abarticlar \\
& - sequels post tratumatic \\
Nervous System & - SNC and peripheric diseases \\
Derm & - psoriazis \\
& - chronic Eczema \\
& - chronic Rasheed \\
Genital System & - chronic inflammations \\
& - secondary sterility \\
Respiratory System & - sfera ORL \\
& - TBC sequelae \\
Endocrine System & - Hypothyroidism \\
& - Obesity \\
& - pituitary dwarfism \\
& - rickets or debility in children \\
\end{tabular}

\section{Bibliography}

1. Cinteză Delia (coordonator) şi colab. (2011). Ghidul balnear. Institutul Naţional de Recuperare medicină fizică şi Balneoclimtologie. Bucureşti.

2. Aniţei Lidia şi colectivul de autori.(1986). Cura Balneoclimatică- indicaţii şi contraindicaţii. Editura medical. Bucureşti.

3. Olga Surdu. (2007). Studiu histologic comparativ al acțiunii nămolului sapropelic de Techirghiol asupra tegumentului. Teză de doctorat. http://www.medicultau.com/sanatateafamiliei/pielea/terapia-cu-namol-peloidoterapia/ tratarea-cu-namol-a-bolilor-de-piele.php http://www.inrmfb.ro/ape.html http://www.naturephoto-cz.eu http://balneoclimateric.blogspot.com 